\title{
Muscular diacylglycerol metabolism and insulin resistance
}

Citation for published version (APA):

Timmers, S., Schrauwen, P., \& de Vogel, J. (2008). Muscular diacylglycerol metabolism and insulin resistance. Physiology \& Behavior, 94(2), 242-51. https://doi.org/10.1016/j.physbeh.2007.12.002

Document status and date:

Published: 01/01/2008

DOI:

10.1016/j.physbeh.2007.12.002

Document Version:

Publisher's PDF, also known as Version of record

Document license:

Taverne

Please check the document version of this publication:

- A submitted manuscript is the version of the article upon submission and before peer-review. There can be important differences between the submitted version and the official published version of record.

People interested in the research are advised to contact the author for the final version of the publication, or visit the DOI to the publisher's website.

- The final author version and the galley proof are versions of the publication after peer review.

- The final published version features the final layout of the paper including the volume, issue and page numbers.

Link to publication

\footnotetext{
General rights rights.

- You may freely distribute the URL identifying the publication in the public portal. please follow below link for the End User Agreement:

www.umlib.nl/taverne-license

Take down policy

If you believe that this document breaches copyright please contact us at:

repository@maastrichtuniversity.nl

providing details and we will investigate your claim.
}

Copyright and moral rights for the publications made accessible in the public portal are retained by the authors and/or other copyright owners and it is a condition of accessing publications that users recognise and abide by the legal requirements associated with these

- Users may download and print one copy of any publication from the public portal for the purpose of private study or research.

- You may not further distribute the material or use it for any profit-making activity or commercial gain

If the publication is distributed under the terms of Article $25 \mathrm{fa}$ of the Dutch Copyright Act, indicated by the "Taverne" license above, 


\title{
Muscular diacylglycerol metabolism and insulin resistance
}

\author{
Silvie Timmers, Patrick Schrauwen, Johan de Vogel* \\ Department of Human Biology, Nutrition and Toxicology Research Institute Maastricht (NUTRIM), Maastricht University, The Netherlands \\ TI Food \& Nutrition (TIFN), Wageningen, The Netherlands
}

Received 31 July 2007; received in revised form 3 December 2007; accepted 5 December 2007

\begin{abstract}
Failure of insulin to elicit an increase in glucose uptake and metabolism in target tissues such as skeletal muscle is a major characteristic of non-insulin dependent type 2 diabetes mellitus. A strong correlation between intramyocellular triacylglycerol concentrations and the severity of insulin resistance has been found and led to the assumption that lipid oversupply to skeletal muscle contributes to reduced insulin action. However, the molecular mechanism that links intramyocellular lipid content with the generation of muscle insulin resistance is still unclear. It appears unlikely that the neutral lipid metabolite triacylglycerol directly impairs insulin action. Hence it is believed that intermediates in fatty acid metabolism, such as fatty acyl-CoA, ceramides or diacylglycerol (DAG) link fat deposition in the muscle to compromised insulin signaling. DAG is identified as a potential mediator of lipid-induced insulin resistance, as increased DAG levels are associated with protein kinase $\mathrm{C}$ activation and a reduction in both insulin-stimulated IRS-1 tyrosine phosphorylation and PI3 kinase activity.

As DAG is an intermediate in the synthesis of triacylglycerol from fatty acids and glycerol, its level can be lowered by either improving the oxidation of cellular fatty acids or by accelerating the incorporation of fatty acids into triacylglycerol.

This review discusses the evidence that implicates DAG being central in the development of muscular insulin resistance. Furthermore, we will discuss if and how modulation of skeletal muscle DAG levels could function as a possible therapeutic target for the treatment of type 2 diabetes mellitus. (C) 2007 Elsevier Inc. All rights reserved.
\end{abstract}

Keywords: Diacylglycerol; Protein kinase C; Skeletal muscle insulin resistance; Lipid accumulation

Abbreviations: DAG, diacylglycerol; TAG, triacylglycerol; FFA, free fatty acids; IMTG, intramyocellular triacylglycerol; IR, insulin receptor; IRS-1, insulin receptor substrate-1; PI3K, phosphatidylinositol 3 kinase; PKC, protein kinase C; $\mathrm{PIP}_{2}$, phosphatidylinositol 3,4 bis-phosphate; $\mathrm{PIP}_{3}$, phosphatidylinositol 3,4,5 triphosphate; PDK1, phosphoinositide-dependent kinase 1; TZD, Thiazolidinediones; PPAR $\gamma$, peroxisome proliferator receptor $\gamma$; LCACoA, long-chain acylCoA; SPT, serine palmitoyltransferase; TNF $\alpha$, tumor necrosis factor $\alpha$; PLD, phospholipase D; PC, phosphatidylcholine; G3P, glycerol-3-phosphate; GPAT, glycerol-3-phosphate acyltransferase; LPA, lysophosphatidic acid; LPAAT, lysophosphatidate acyltransferase; PA, phosphatidic acid; PPH-1, phosphatidic acid phosphohydrolase; DGAT, diacylglycerol acyltransferase; HSL, hormone sensitive lipase; ATGL, AdiposeTriGlycerideLipase; PS, phosphatidyl serine; cPKC, classical protein kinase $\mathrm{C}$; $\mathrm{nPKC}$, novel protein kinase $\mathrm{C}$; aPKC, atypical protein kinase C; SCD-1, stearoyl-CoA desaturase; CPT-1, carnitine palmitoyl transferase 1; MGAT, acyl-coA: monoacylglycerol acyltransferase.

* Corresponding author. Nutrition and Toxicology Research Institute Maastricht (NUTRIM), Department of Human Biology, Maastricht University, P.O. Box 616, 6200 MD Maastricht, The Netherlands. Tel.: +31 43 3881507; fax: +31433670976 .

E-mail address: j.devogel@hb.unimaas.nl (J. de Vogel).

\section{Introduction}

During the past decades, the prevalence of obesity in children and adults has increased enormously. This is a major health issue at the moment, because the incidence rate of obesity is currently reaching epidemic proportions and given the current trend there are no signs that it will decrease. Obesity is a condition characterized by excess body fat and is defined with a body mass index (in $\mathrm{kg} / \mathrm{m}^{2}$ ) $\geq 30$. Currently, $30 \%$ of American adults are classified as obese and 1 out of every 6 children is overweight according to the National Health and Nutrition Examination Survey [1]. Obesity is clearly recognized as a deleterious condition and predisposes individuals to a range of health complications including: insulin resistance [2], type 2 diabetes [2], hypertension, cardiac failure, and atherosclerosis, which accounts for a high percentage of the current health care costs [3-6].

Although the association between obesity and insulin resistance is clearly shown in epidemiologic literature, the pathophysiology of obesity and insulin resistance needs to be further 
elucidated. Insulin resistance is characterized by the reduced ability of the pancreatic hormone insulin to promote peripheral glucose disposal and suppress hepatic glucose output. Skeletal muscle is considered as one of the primary tissues in glucose homeostasis, because it accounts for $75-80 \%$ of whole body insulin-stimulated glucose uptake $[7,8]$. Therefore, skeletal muscle insulin resistance is a major determinant of hyperglycemia and type 2 diabetes mellitus. Skeletal muscle insulin resistance has been associated with the accumulation of total body fat [9]. However, an even stronger association has been shown between intramyocellular fat storage and insulin resistance in animals $[10,11]$ and humans $[12,13]$. This suggests that aberrant storage of lipids or lipid intermediates in skeletal muscle contributes to the development of insulin resistance [14].

The aim of this review is to discuss the association between skeletal muscle insulin resistance and ectopic lipid accumulation. First we will discuss the normal insulin signalling cascade and the interference of ectopic lipids. Next, the role of the different lipid intermediates in the development of muscular insulin resistance will be highlighted, with a focus on DAG.

\section{Insulin signalling pathways promoting glucose uptake}

Insulin promotes the uptake of glucose from the plasma into skeletal muscle (Fig. 1). The insulin receptor (IR) is an $\alpha_{2} \beta_{2}$ heterodimeric transmembrane protein that possesses intrinsic protein tyrosine kinase activity. After binding of insulin to the extracellular domain of the $\alpha$ subunit, the receptor undergoes conformational changes that result in autophosphorylation of specific tyrosine residues in the cytoplasmic domain of the $\beta$ subunit. Autophosphorylation of tyrosine residues stimulates the catalytic activity of receptor tyrosine kinase and creates recruitment sites for insulin receptor substrate proteins, such as insulin receptor substrate-1 (IRS-1) [15-17]. Phosphatidyl inositol 3- kinase (PI3K) is a target of IRS proteins that phosphorylates phosphatidyl inositol 4,5-biphosphate $\left(\mathrm{PIP}_{2}\right)$ to form phosphatidyl inositol 3,4,5-triphosphate $\left(\mathrm{PIP}_{3}\right)$, which in turn activates phosphatidyl inositol-dependent kinase1 (PDK1). This Ser/Thr kinase then activates protein kinase $\mathrm{B}$ ( $\mathrm{PKB}$ or $\mathrm{Akt}$ ) and the atypical protein kinase $\mathrm{C}(\mathrm{PKC})$ isozymes $\mathrm{PKC} \zeta$ and $\mathrm{PKCl} / \lambda$ [18]. Both Akt and the atypical PKCs have been implicated in the translocation of the glucose transporter 4 (GLUT4) from the cytosol to the plasma membrane, which mediates glucose uptake.

\section{Lipid-induced insulin resistance in skeletal muscle}

In the past 15 years, evidence has accumulated that increased plasma free fatty acid (FFA) levels are associated with insulin resistance [19-21]. Indeed, most insulin-resistant obese people have elevated plasma FFA levels and acute elevations of plasma FFA in diabetic or non-diabetic individuals induces insulin resistance in a dose-dependent way [22-24]. Moreover, lowering plasma FFA levels by Acipimox a derivate of nicotinic acid, which inhibits lipolysis, normalized insulin sensitivity in obese and non-diabetic subjects, and significantly improved it in obese diabetic patients [25]. In addition, treatment of high-fat fed mice with acipimox lowered FFAs in the plasma and significantly improved insulin sensitivity [26].

Several studies have aimed to elucidate the role of elevated FFA levels in the onset of insulin resistance. Diet intervention studies in rodents showed that insulin resistance develops after a few weeks of high-fat feeding and is associated with the accumulation of intramuscular triacylglycerol (IMTG) [10,27-30]. Another frequently used model in the literature to investigate the role of FFA in the onset of insulin resistance is the infusion of a lipid emulsion to increase the level of plasma fatty acids before and during a hyperinsulinemic euglycemic clamp. Elevating FFA levels by means of lipid infusion in humans, decreased insulin-

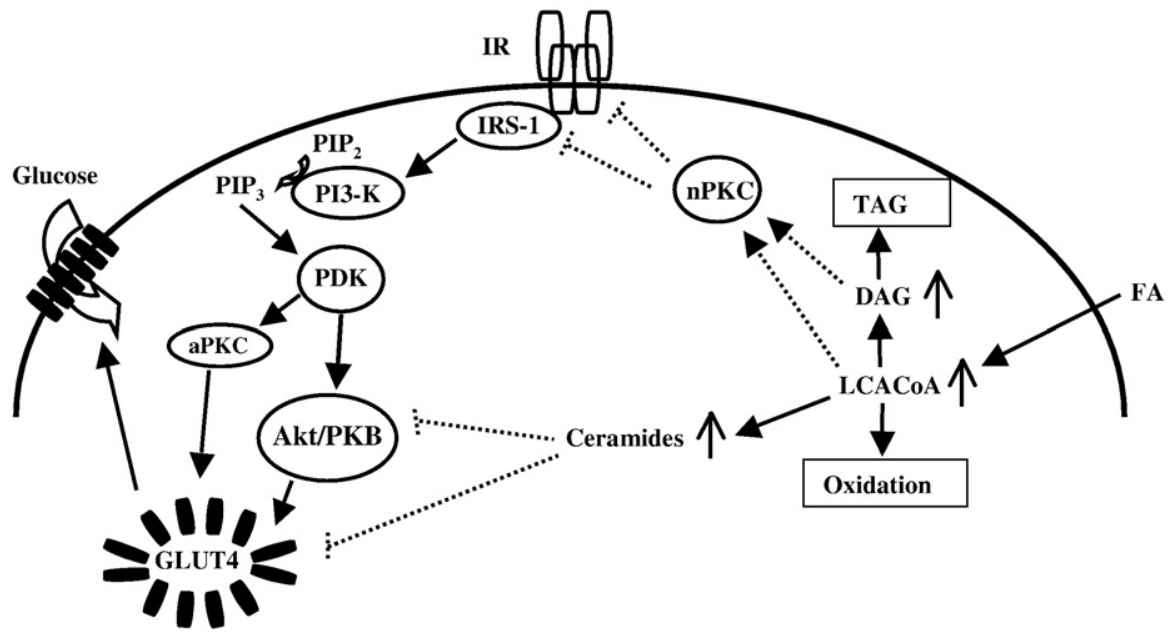

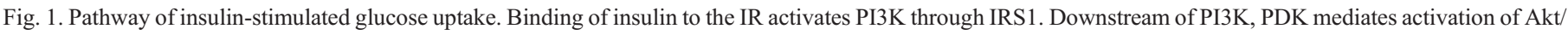

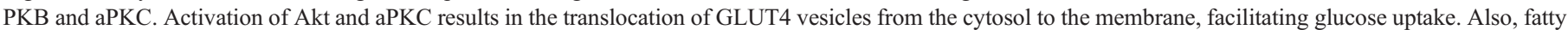

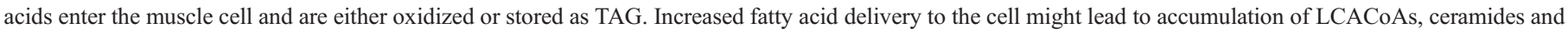

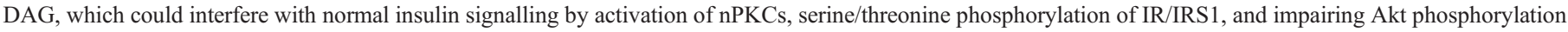

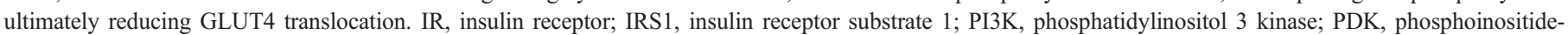

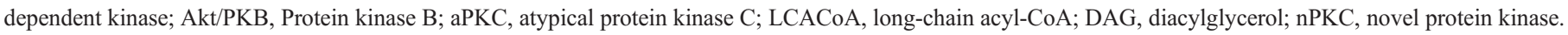


stimulated glucose uptake in skeletal muscle, which provides evidence that FFA interfere with insulin action $[22,31,32]$. Interestingly, insulin resistance developed only $2-4 \mathrm{~h}$ after an acute increase in the plasma FFA concentration and it takes an equally long time to disappear after plasma FFA levels have returned to basal levels. From these observations, it can be concluded that the insulin desensitizing effect is not due to circulating fatty acids. It has therefore been suggested that fatty acids first need to accumulate in skeletal muscle before they can interfere with insulin signalling [33].

Indeed, ectopic storage of lipids as IMTG might play an important role in the onset of insulin resistance. This hypothesis is supported by experiments with lipodystrophic mice and humans. Lipodystrophy is a disorder characterized by the partial or complete loss of adipose tissue. Excess calorie ingestion in these mice or humans leads to high levels of ectopic lipid accumulation with decreased insulin sensitivity as a result. Interestingly, Gavrilova et al. [34] and Kim et al. [35] showed that this ectopic lipid deposition could be reduced by transplanting adipose tissue from wild-type mice into A-ZIP/F-1 mice, which have a severe form of lipoatrophic diabetes. Transplantation of wild-type fat reversed hyperglycemia, lowered insulin levels, and improved muscle insulin sensitivity, together with a reduction in ectopic fat storage. These studies suggest that not only lowering of ectopic fat depots but also adipose tissue secretory proteins may be important for normal glucose and lipid homeostasis. In that respect, treatment of lipodystrophic mice and humans with the anorexogenic adipocyte-derived hormone leptin $[36,37]$ resulted in a remarkable improvement in insulin-stimulated liver and muscle glucose metabolism together with lowering fat stores [38].

Also, treatment of obese Zucker rats with Thiazolidinediones (TZD) support the hypothesis that muscular fat accumulation leads to insulin resistance. TZDs activate peroxisome proliferator $\gamma(\operatorname{PPAR} \gamma)$ receptors in adipocytes, and promote adipocyte differentiation, which results in the redistribution of fat from liver and muscle into adipocytes and as a consequence an overall improvement in insulin sensitivity [39]. However, recently it has been shown that treatment of type 2 diabetics with the PPAR $\gamma$ agonist Pioglitazone may improve insulin sensitivity both by affecting serum adipokine concentrations and by reducing the intracellular triglyceride content of liver and skeletal muscle [40].

\section{IMTG versus lipid intermediates}

Although many studies associate IMTG storage with insulin resistance, the causality is not entirely validated. First of all, endurance training in obese humans improves skeletal muscle insulin resistance with little or no changes in IMTG concentrations [41,42]. Furthermore, Phillips et al. [43] have shown that endurance training in healthy volunteers progressively increased IMTG deposits, while simultaneously improving insulin sensitivity. In line with this, our group has recently shown that a shortterm endurance training program increased IMTG content before insulin sensitivity was improved [44]. Another remarkable finding is that elite endurance trained athletes are amongst the most insulin-sensitive people and yet exhibit extremely high IMTG concentrations [45]. This metabolic paradox suggests that it is unlikely that the IMTG pool is responsible for the reduced insulin action. Nowadays, this paradox is explained by the accumulation of lipid intermediates such as fatty acyl-CoA, ceramides and diacylglycerol, which might suppress insulin sensitivity [46] (Fig. 1).

\subsection{Long-chain acyl-CoAs}

Long-chain acyl-CoAs (LCACoAs) are the metabolically activated form of intracellular fatty acids produced by the action of the enzyme Acyl-CoA synthetase. LCACoAs are transported into the mitochondria for Beta-oxidation or used as an intermediate in the production of other lipid species. Increased uptake of FFAs or breakdown of IMTG stores could lead to high levels of intracellular LCACoAs. This form of lipid may influence energy metabolism acutely by changing substrate availability or by altering key enzyme activities via allosteric regulation. Increased muscular LCACoA levels have been associated with insulin resistance based on numerous animal and human studies in which the LCACoA levels are modulated by different dietary interventions or acutely via lipid infusion [27,47-49]. In addition, incubation of isolated rat soleus muscle strips with fatty acids reduced glucose uptake in a manner that correlated with the accumulation of LCACoA [50]. Moreover, interventions such as a single exercise bout or overnight fasting decreased the intramuscular LCACoA content in 3 week high-fat fed rats and increased insulin-stimulated glucose uptake into skeletal muscle [51]. Several mechanisms have been postulated that link LCACoAs with decreased insulin signalling. LCACoAs were shown to modulate enzyme activity of hexokinase in muscle and therefore directly regulate glucose influx. In liver, LCACoAs have been shown to modulate directly or indirectly the activity of key metabolic enzymes such as acyl-coA synthase, glucokinase, glucose-6-phosphatase, hormone sensitive lipase or AMP kinase [52]. Alternatively, LCACoAs might interfere with insulin signalling by activation of PKC isozymes [53,54]. However, despite the afore-mentioned evidence, LCACoA could also be a marker of increased muscular ceramide or DAG levels, which are associated with insulin resistance, as elevated LCACoA levels are often accompanied by elevated levels of the latter.

\subsection{Ceramides}

Ceramides can be generated from two fatty acids and serine via 4 enzymatic steps. They have a function as signalling molecule in several important physiological events including inhibition of cell division and stimulation of apoptosis. The synthesis of ceramides largely depends on the availability of long-chain saturated fatty acids, which together with serine are the rate limiting substrates in the de novo ceramide synthesis by serine palmitoyltransferase (SPT) [55]. SPT is specific for saturated FFAs, in contrast to incorporation of the second FFA in ceramides, which can originate from saturated or unsaturated FFAs [55]. Ceramides are also proposed to play a role in the development of insulin resistance since elevated ceramide levels have been shown in tissues of insulin-resistant animals [56], in skeletal muscle of lipid infused humans [57], and in skeletal muscle of obese insulin-resistant 
humans [58]. Ceramides could accumulate in the muscle via hydrolysis of sphingomyelin, one of the four common phospholipids found in the lipid bilayer of the cell, catalysed by the enzyme sphingomyelinase [59], or via de novo synthesis from saturated fatty acids [60]. Tumor necrosis factor $\alpha$ (TNF $\alpha)$ has also been shown to stimulate sphingomyelinase and hence increase ceramide levels [61]. This might be important since an increased inflammatory state is also observed in obese individuals [62]. Ceramides might mediate their antagonistic effect on insulin signalling via inhibition of the phosphorylation of Akt $[62,63]$, independently of changes in the ability of insulin to stimulate IRS1 phosphorylation or PI3 kinase activation. Indeed, Hajduch et al. [64] showed that incubation of L6 muscle cells with the shortchain ceramide analogue $\mathrm{C} 2$-ceramide for $2 \mathrm{~h}$ resulted in a complete loss of insulin-stimulated glucose transport and glycogen synthesis, caused by a failure to activate Akt. Also incubation of $\mathrm{C} 2 \mathrm{C} 12$ muscle cells with the saturated fatty acid palmitate leads to elevation of ceramide and inhibition of Akt and thereby reducing insulin signalling [63]. Moreover, blocking ceramide synthesis in palmitate-treated myotubes, restored Akt activation by insulin [65]. Taken together, there is evidence for a role of ceramides in the development of muscular insulin resistance. However a precise understanding of the molecular mechanism by which ceramides regulate insulin action is still elusive [62]. For a more extensive review about the role of ceramides in insulin resistance see Summers et al. [62].

\section{3. $D A G$}

DAG is another interesting candidate that might be responsible for lipid-induced insulin resistance. DAG levels have been found to be associated with insulin resistance after high-fat feeding in rats, in obese Zucker $(f a / f a)$ rats and in denervated soleus muscle [66-71].

DAG can be derived from multiple sources (Fig. 2). First of all, breakdown of phospholipids by the enzyme phospholipase C (PLC) can generate DAG [72]. Secondly, DAG can be generated from phospholipase D (PLD) -mediated hydrolysis of phosphatidylcholine (PC). However, in case of lipid-induced insulin resistance a third principal source, the de novo synthesis of DAG by esterification of two LCACoAs to glycerol-3-phosphate, is probably the most important route. During the first acylation step catalyzed by glycerol-3-phosphate acyltransferase (GPAT), a fatty acyl-CoA is linked to the first ( $s n-1)$ position of the glycerol molecule, giving rise to lysophosphatidic acid (LPA). The second fatty acyl-CoA is attached to the second (sn-2) position of the glycerol backbone by the enzyme lysophosphatidate acyltransferase (LPAAT), forming a second precursor: phosphatidic acid (PA). The latter is subsequently transformed into DAG through the action of phosphatidic acid phosphohydrolase (PPH). TAG could then be formed by the action of diacylglycerol acyltransferase (DGAT) [73]. Alternatively, hydrolysis of TAG by the activity of lipases also results in increased DAG levels. Until recently, hydrolysis of TAG was believed to occur via hormone sensitive lipase (HSL). However, the observation that HSL deficient mice accumulate DAG [74], was the first indication that another myocellular lipase should be present for
DAG synthesis

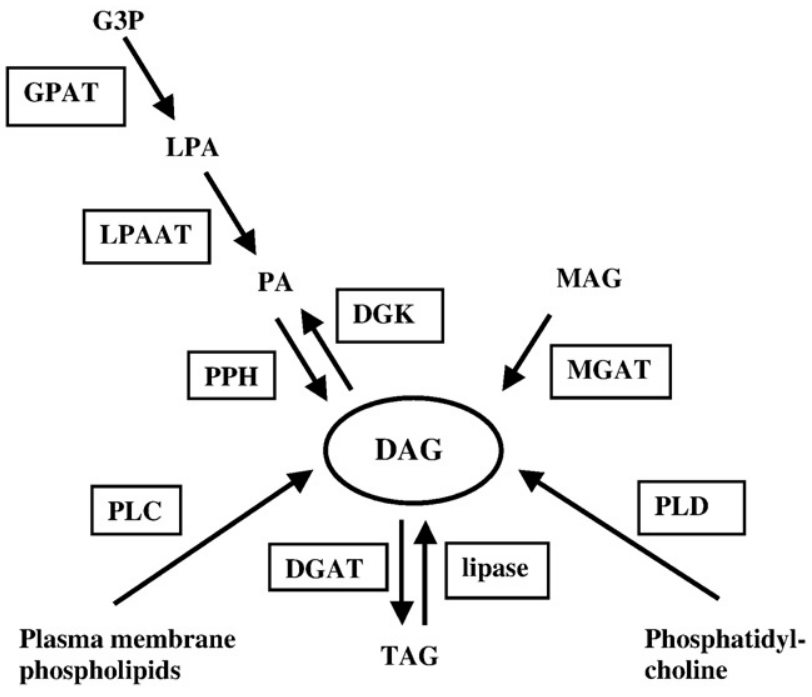

Substrate breakdown to generate DAG

Fig. 2. Schematic representation of the synthesis of DAG. Upper part of the figure shows the synthesis of DAG from G3P or MAG. The lower part of the figure shows the generation of DAG by enzymatic breakdown of TAG, phospholipids, or PC. G3P, glycerol-3-phosphate; LPA, lysophosphatidic acid; PA, phosphatidic acid; DAG, diacylglycerol; TAG, triacylglycerol; MAG, mono acylglycerol; GPAT, glycerol-3-phosphate acyltransferase; LPAAT, lysophosphatidate acyltransferase; PPH, phosphatidic acid phosphohydrolase; DGK, diacyl glycerolkinase; MGAT, acyl-coA: monoacylglycerol acyltransferase; PLC, phospholipase; PLD, phospholipase D; DGAT, diacylglycerol acyltransferase.

hydrolysis of IMTG. Recently, AdiposeTriGlycerideLipase (ATGL) [75-77] was discovered and this enzyme is now regarded as the main lipase responsible for hydrolysis of TAG to DAG. Indeed overexpresssion of ATGL resulted in massive increases in DAG levels [77] and might increase the risk to develop insulin resistance.

DAG is thus important as an intermediate in TAG metabolism, and it also occupies a central position in the biosynthesis of glycerophospholipids, which are the main components of cell membranes [73]. Furthermore, DAG is an important second messenger involved in intracellular signalling and thought to have detrimental effects on insulin signalling through its ability to activate PKC [14].

$\mathrm{PKC}$ is a family of structurally and functionally related proteins derived from multiple genes after alternative splicing $[78,79] . \mathrm{PKC}$ is activated in a response to a transient increase in DAG or after the exposure to exogenous tumour-promoting agents known as phorbol esters, which results in the translocation of the protein from the cytosol to the plasma membrane. A total of 12 isozymes of PKC have been cloned and characterized so far, which are classified into three different subfamilies [80]. Each isoform shows a different pattern of tissue distribution, substrate specificity and cofactor requirement. The classical PKC isoforms (cPKC $\alpha, \beta I, \beta I I, \gamma)$ are calcium- and phospholipids-dependent and are activated by phosphatidylserine (PS), calcium and DAG (or phorbol ester). The novel PKCs (nPKC $\delta, \varepsilon, \theta, \eta$ ) are calciumindependent but phospholipids-dependent; they require PS and 
DAG for activation. The atypical PKC isoforms $(\mathrm{aPKC} \zeta, \mathrm{L} / \lambda)$ are calcium and phospholipid independent. Although the aPKCs are dependent on the presence of PS for their catalytic activity, these isoforms are not activated by calcium, DAG or phorbol esters.

During activation these kinases can translocate from the cytosol to the cell membrane and the extent to which PKC is found in membrane fractions is commonly used as a measure of its activation. As a consequence of prolonged activation, PKC can also be downregulated by proteolysis.

Activation of one or more PKC isoforms leads to a variety of biological responses, including changes in cell proliferation and differentiation, transmembrane ion transport, glucose and lipid metabolism, smooth muscle contraction and gene expression [81-83]. Very little is known about the functional specificity of different $\mathrm{PKC}$ isoforms. Animal studies have mainly implicated the $\mathrm{nPKCs}$, $\mathrm{PKC} \varepsilon$, and $\mathrm{PKC} \theta$ in muscle insulin resistance $[66,84,85]$ whereas activation of aPKCs can lead to insulinmediated GLUT4 translocation to the plasma membrane, which enables glucose uptake in skeletal muscle [86].

Nowadays, DAG activation of the novel PKC isoforms is considered as a major determinant of lipid-induced insulin resistance.

One mechanism through which PKC could account for the insulin signalling defect is phosphorylation of the IR. It seems that serines on the $\beta$ subunits of the IR kinase are an important target for PKC phosphorylation [87]. Serine phosphorylation, in stead of the normal insulin-stimulated tyrosine phosphorylation, has been considered to be one of the mechanisms for inhibition of IR function [88]. Specifically, the structural mechanism appears to involve IRS protein dissociation from the insulin receptor by inducing conformational changes, thereby impeding access to tyrosine phosphorylation sites $[89,90]$.

In the immediate downstream signalling events following IR stimulation, PKCs also phosphorylate and modulate the IRS proteins [91]. There are over 70 potential serine phosphorylation sites on IRS-1, and in general, serine phosphorylation seems to negatively regulate IRS signalling. Studies have demonstrated hyper-serine phosphorylation of IRS-1 on $\operatorname{ser}^{302}, \operatorname{ser}^{307}, \operatorname{ser}^{612}$, and $\operatorname{ser}^{632}$ in several insulin-resistant rodent models [92-95], as well as in lean insulin-resistant offspring of type 2 diabetic parents [96]. In vitro studies have shown that serine phosphorylation may lead to dissociation between the IR/IRS-1 and/or IRS-1/PI3 kinase, preventing PI3 kinase activity [97-100]. Ultimately, this IRS-1 inhibition will result in decreased insulin-stimulated glucose transport (GLUT 4) activity and glucose uptake.

\section{A link between DAG and insulin resistance}

In rodents, a number of studies have provided evidence for the association between aberrant activation of PKC and decreased insulin sensitivity, especially associated with increased lipid loading in insulin-responsive tissues. Alterations in specific isoforms of PKC were observed in skeletal muscle of high-fat fed rats. An increase in the proportion of membrane-localized $\mathrm{PKC} \varepsilon, \mathrm{PKC} \theta$ and $\mathrm{PKC} \delta$, which correlated with IMTG and DAG content was found in red skeletal muscle from high-fat fed rats, suggesting chronic activation, while the diminished total amounts of PKC $\theta$ and PKC $\delta$ also indicated proteolysis [66]. In addition, a five-hour lipid infusion was also shown to increase the translocation of PKC $\theta$ from the cytosol to the membrane in skeletal muscle [85]. A study by Yu et al. [101] showed that infusion of a lipid emulsion in rats resulted in a three-fold increase in intracellular DAG mass, which was associated with PKC $\theta$ activation. Coinciding with the increased PKC $\theta$ activity, they observed a $30 \%$ reduction in insulin activation of IRS-1 tyrosine phosphorylation and approximately a $50 \%$ reduction in IRS-1 associated PI3 kinase activity. PKC activity, DAG content and $\mathrm{PKC} \varepsilon$ and $\mathrm{PKC} \theta$ membrane localization were also increased in a study of obese Zucker rats [70]. Moreover, treatment of high-fat fed rats with an antilipolytic drug rosiglitazone, which reduced muscle DAG and IMTG levels, improved insulin sensitivity and reversed the diet-induced changes in $\mathrm{nPKC}$ expression [102]. Similarly, rapid reversal of insulin resistance in high-fat fed rats by an acute dietary intervention with one high-glucose low-fat meal also normalized PKC $\theta$ activation [103]. Furthermore, PKC $\theta$ knockout mice are protected from fat-induced insulin resistance in skeletal muscle. Kim et al. [92] showed that in contrast to wild-type mice, PKC $\theta$ knockout mice had no decreases in insulin-stimulated tyrosine phosphorylation of IRS-1 and IRS-1-associated PI3 kinase activity after a fivehour lipid infusion.

In humans, both PKC $\theta$ protein content and activity were significantly increased in the rectus abdominus skeletal muscle from obese diabetic subjects compared to skeletal muscle from obese, normoglycemic controls, suggesting involvement of this isoform in type 2 diabetes [104]. Recently, the same group has shown that fatty acid induced muscle insulin resistance in normal volunteers was found to be associated with increased DAG mass and with $\mathrm{PKC}$ isoform $\beta 2$ and $\theta$ membrane translocation [32].

Taken together, these studies strongly support a link between IMTG, DAG accumulation, insulin resistance and activation of $\mathrm{PKC}$, although the relative roles of the different PKC isoforms involved remain unclear.

\section{Modulation of DAG}

As reviewed above, substantial evidence links DAG accumulation, via activation of the nPKC isoforms, to the development of muscular insulin resistance. This makes DAG content an important target for therapeutic interventions.

As DAG is an intermediate in the synthesis of TAG from glycerol and fatty acids, its levels can be lowered either by improving the oxidation of cellular fatty acids by genetically modifying carnitine palmitoyl transferase 1 (CPT1) [105], or by accelerating the incorporation of fatty acids into TAG. The latter can be achieved by genetically modifying enzymes that are involved in the synthesis and hydrolysis of TAG, such as diacylglycerol acyltransferase (DGAT), glycerol-3-phosphate acyltransferase (GPAT), and stearoyl-CoA desaturase (SCD-1) [106-108].

DGAT catalyzes the final step in TAG synthesis by facilitating the linkage of $s n$-1,2-diacylglycerol with LCACoA. DGAT exists in two primary isoforms: DGAT1 and DGAT2 $[108,109]$. DGAT1 is ubiquitously expressed in human and mouse tissue, with the 
highest expression levels in the small intestine and white adipose tissue [108] and it appears to have a role in fat absorption and energy homeostasis [110]. DGAT2 is primarily expressed in liver and white adipose tissue [109]. Revealing the function of DGAT2 has proven to be more difficult because homozygous DGAT2 knockout mice die shortly after birth due to severe lipopenia and impaired skin barrier function [111].

Since DGAT1 is present in all insulin-sensitive tissues, manipulation of DGAT1 activity could be an attractive target for manipulation of DAG content. It can be hypothesized that an increase in DGAT1 activity would increase the conversion of DAG into TAG, thereby lowering DAG content and improving insulin sensitivity. Conversely, ablation of DGAT1 could be expected to result in elevated DAG levels. Consistent with the role of DGAT1, mice lacking DGAT1, showed 30-40\% decreased levels of TAG in adipose tissue and skeletal muscle [112]. In accordance with the decrease in adiposity, $\mathrm{DGAT}^{-}{ }^{-}$mice have an improved whole body insulin sensitivity as shown by an increase in glucose infusion rate during hyperinsulinemic euglycemic clamp studies [112]. Insulin-stimulated glucose transport is increased in skeletal muscle and white adipose tissue of DGAT1 deficient mice, and the insulin-stimulated activity of key molecules in the insulin signalling pathway, such as PI3K and Akt is also increased in skeletal muscle of these mice [113]. Partial deletion of DGAT1 also appeared to improve insulin sensitivity, as evidenced by decreased blood glucose levels after intraperitoneal injections of insulin in inbred DGAT1-heterozygous $\left(\mathrm{DGAT} 1^{+} /{ }^{-}\right.$) mice [114].

Although it is not surprising that the leanness in DGAT1 deficient mice leads to an improved insulin sensitivity, the precise mechanisms that contribute to the insulin sensitivity remain unresolved. It is hypothesized that DGAT1 deficiency in white adipose tissue alters its endocrine function [112,115], thereby promoting energy expenditure and sensitivity to insulin [116]. To test this hypothesis, white adipose tissue was transplanted from DGAT1 deficient mice into wild-type recipient mice and its effects on glucose disposal and the response to a high-fat diet was monitored. The recipient mice acquired partial obesity resistance, increased insulin-stimulated glucose disposal, and enhanced activation of the insulin signalling pathway [113,117]. These results strongly suggest that the altered expression and secretion of adipocyte-derived factors exert beneficial effects on energy and glucose metabolism. It therefore is of considerable interest to determine the adipocyte-derived factors that contribute to the overall improved insulin sensitivity in DGAT1 deficient mice. It appears that adipocytes that lack a functional DGAT1 enzyme have an increased leptin sensitivity, and DGAT1 deficient mice lose more weight than wild-type mice in response to subcutaneous leptin infusion [112]. Furthermore, expression of adiponectin, a white adipose tissue-derived hormone that improves insulin sensitivity and increases fatty acid oxidation, is also increased in DGAT1 deficient mice $[118,119]$.

Although tissue TAG levels are reduced in DGAT deficient mice, levels of DAG and fatty acyl-coA, substrates of the DGAT reaction, are not elevated and even tended to be lower in skeletal muscle and liver [112]. These findings disagreed with the expectations that based on the function of DGAT1, DAG levels would be increased, which would worsen the insulin sensitivity. Yen et al. [120] proposed that the absence of muscle DAG accumulation might be explained in part by the loss of acylCoA: monoacylglycerol acyltransferase (MGAT) activity mediated via DGAT1. This implies that DGAT1 could catalyze the sequential esterification of two fatty acyl moieties to convert monoacylglycerol to diacylglycerol and then to triacylglycerol. In other words, fatty acid uptake might be altered in $\mathrm{DGAT}^{-}{ }^{-}$ mice. If this is indeed a function of DGAT in intact cells still requires further testing.

Contrary to the above mentioned findings, skeletal musclespecific transgenic overexpression of DGAT1 in mice protected against fat-induced insulin resistance [121]. Myocellular overexpression of DGAT1 resulted in decreased DAG and ceramide levels and increased IMTG levels. The reduction in high-fat diet-induced insulin resistance could in part be attributed to attenuation of fat-induced activation of DAG-responsive PKCs. The level of membrane-bound PKC activity of all the DAGresponsive isoforms combined were lower in the high-fat fed DGAT overexpressing mice than in high-fat fed wild-type mice, but were comparable to the levels of normal chow-fed wild-type mice. Measurement of DAG-sensitive PKC isoforms $\beta I I, \varepsilon$, and $\theta$ confirmed these results.

Moreover, a role for DGAT1 attenuating lipid-induced insulin resistance was shown in isolated muscles from whole body DGAT1 knockout mice, muscle-specific DGAT1 overexpressing mice and wild-type mice, which were incubated with a combination of palmitate and oleate [121]. Muscle from DGAT1 overexpressing mice showed enhanced insulin sensitivity compared to muscle from wild-type mice, whereas DGAT1 deficiency was associated with diminished skeletal muscle insulin sensitivity upon administration of fatty acids. The attenuation of fatty acid-induced insulin resistance in DGAT overexpressing mice was associated with decreased DAG and ceramide levels comparable with levels observed in control mice. In accordance, the decreased insulin sensitivity in soleus muscle of DGAT1 deficient mice correlated with increased accumulation of DAG mass and increased ceramide levels. These results are in contrast with the earlier mentioned results of Chen et al. [112], who showed decreased DAG levels in whole body DGAT1 knockout mice, and an improved overall insulin sensitivity, again suggesting that altered systemic factors (i.e. circulating adipokines) in these mice may have affected the phenotype observed in skeletal muscle [113].

Thus, it seems that the levels of DGAT1 in skeletal muscle indeed determine muscle insulin sensitivity and susceptibility to fatty acid-induced insulin resistance, as evidenced by decreased DAG and ceramide levels.

Improving the oxidation capacity of muscle cells can also modulate DAG levels. Indeed, Sebastión et al. [105] showed that incubation of L6E9 muscle cells overexpressing CPT1 with palmitate were protected against fatty acid-induced insulin resistance by inhibiting both the accumulation of lipid metabolites such as DAG and ceramides, and the activation of PKC $\theta$ and PKC $\zeta$. In the absence of palmitate incubation CPT1 overexpression affected neither basal nor insulin-stimulated glucose metabolism. After a $16 \mathrm{~h}$ incubation with palmitate, insulin no 
longer stimulated glucose uptake in control cells. This insensitivity correlated with the accumulation of TAG, DAG and ceramide. However, in CPT1 overexpressing cells insulin still stimulated glucose uptake after palmitate treatment to the same extent as in control cells without palmitate addition. This protection was associated with a reduction of palmitate incorporation into cellular lipids, and reduced levels of DAG and ceramides.

Another way to manipulate DAG may be via acute exercise and/or endurance training. Bruce et al. [41] showed that an 8 week endurance training program increased insulin sensitivity, accompanied by decreased levels of DAG. This decrease in DAG was not accompanied by changes in IMTG content. Schenk and Horowitz [122] tested the hypothesis that a single session of exercise in human subjects would protect against fatty acidinduced insulin resistance, when subjects received a $4 \mathrm{~h}$ lipid infusion. It was shown that one single bout of exercise was capable of markedly improving insulin sensitivity. This was accompanied by an increase increased IMTG content, suggesting that a single bout of exercise may reduce the storage of fatty acids as metabolically unfavourable fatty acid metabolites. A possible mechanism for increased IMTG storage after exercise was the enhancement of the lipogenic capacity of skeletal muscle, as evidenced by increased protein expression of mGPAT, DGAT1, and SCD1. Ikeda et al. [123] also showed that a two week exercise training in mice increased the gene expression of DGAT1.

Next to exercise and genetic manipulation of genes involved in TAG metabolism, DAG may also be manipulated by dietary fatty acid composition. Studies in lipid-pretreated cells have shown that different types of fatty acids can lead to differences in the content of fatty acid intermediates $[124,125]$. Chavez et al. [124] showed that incubation of $\mathrm{C} 2 \mathrm{C} 12$ myotubes with palmitate, but not oleate, inhibited insulin-stimulated glycogen synthesis accompanied by accumulation of DAG and ceramides. Incubation with longer chain saturated fatty acids also reduced insulin sensitivity and elevated DAG and ceramide levels, whereas incubation with medium chain fatty acids had no effect on insulin sensitivity or accumulation of DAG or ceramides. Similar results were obtained by Montell et al. [125] and Gaster et al. [126]. They showed that incubation of muscle cells with palmitate increased the incorporation of fatty acids into DAG whereas the unsaturated fatty acids were diverted towards storage in the TAG pool or present in the FFA pool [125].

An explanation for the effect of fatty acid type on the conversion towards TAG might be a different affinity of DGAT1 for the saturated versus the unsaturated fatty acids [125]. Coleman and Bell [127] showed that DGAT, isolated from fat cells, had a maximal activity when di-olein was used, whereas DGAT activity was minimal when di-palmitin was used as a substrate. Likewise, in L6 myotubes, DGAT also had a maximal activity for unsaturated acyl-CoAs, compared with saturated acyl-CoAs [128]. Moreover, Montell et al. [125] showed that increasing the concentration of oleate in a mixture of palmitate and oleate progressively declined the incorporation of palmitate into DAG, whereas the TAG concentration increased.

Taken together, these studies suggest that especially saturated fatty acids lead to the accumulation of DAG in muscle cells, whereas unsaturated fatty acids preferably stimulate the conversion into TAG. In that context it is interesting to note that it has been shown that diets high in saturated fatty acids are more prone to result in insulin resistance compared to diets rich in unsaturated fatty acids in humans [129].

However, the number of studies that have addressed the effects of different fatty acid subtypes on insulin resistance in vivo in humans and animals is scarce. A possible way to examine this relationship is by means of the lipid infusion model. Studies using lipid emulsions to increase plasma fatty acid levels and muscular fatty acid intermediates in rats and humans showed an increase in DAG associated with increased PKC activity and decreased insulin sensitivity in rats and humans $[32,101]$. Both studies only observed an increase in the level of muscular DAG and not in intracellular ceramide or TAG concentrations, suggesting that these metabolites do not play a major role in mediating fatty acid-induced insulin resistance in skeletal muscle. This model could also be used to examine the effect of fatty acid subtype on lipid intermediate accumulation but until now studies have almost exclusively used intralipid, which is mainly composed of polyunsaturated fatty acids, as lipid emulsion. Therefore, it would be very interesting to study the effects of other lipid emulsions, with increased contribution of saturated fatty acids, on DAG accumulation, DAG type, PKC translocation and muscular insulin resistance.

\section{Conclusion and future perspectives}

In this review, we have summarized the effects of ectopic lipid accumulation on skeletal muscle insulin resistance. Among the many lipid metabolites that might contribute to the onset of insulin resistance, DAG has attracted particular interest. DAG is an intermediate in the synthesis of TAG from FFA and numerous studies have shown an association between DAG accumulation and the degree of insulin resistance.

If indeed the current sedentary life-style and the continuous access to energy-rich food is associated with high DAG levels, modulation of DAG might be an important therapeutic strategy to improve overall insulin sensitivity. It has been shown that DAG can be decreased by physical activity. Furthermore, dietary fatty acid composition has the potential to affect DAG content, although a limited number of publications are available. Therefore, more (human) research is needed to unravel the exact effect of fatty acid composition on DAG levels and insulin resistance.

An area that so far has been hardly addressed is the role that different subtypes of DAG may play in the development of insulin resistance. It can be suggested that the effect of fatty acid saturation and chain length on muscular insulin resistance as observed in muscle cells is not only due to an effect on DAG content, but also on DAG composition. So far, the analysis of different DAG species and their effects on PKC activity or translocation within the cell has been proven difficult, but is an area that certainly deserves further investigation.

\section{Acknowledgements}

This study was funded by TI Food and Nutrition, an alliance of major Dutch food industries, TNO Quality of Life, Zeist, Maastricht University, Wageningen University and Research 
Centre, with financial support from the Dutch government. The research of Dr. P. Schrauwen has been made possible by a fellowship of the Royal Netherlands Academy of Arts and Sciences.

\section{References}

[1] Baskin ML, Ard J, Franklin F, Allison DB. Prevalence of obesity in the United States. Obes Rev 2005;6:5-7.

[2] Mokdad AH, Ford ES, Bowman BA, Dietz WH, Vinicor F, Bales VS, et al. Prevalence of obesity, diabetes, and obesity-related health risk factors, 2001. Jama 2003;289:76-9.

[3] Krauss RM, Winston M, Fletcher RN, Grundy SM. Obesity: impact of cardiovascular disease. Circulation 1998;98:1472-6.

[4] Eckel RH, York DA, Rossner S, Hubbard V, Caterson I, St Jeor ST, et al. Prevention Conference VII: Obesity, a worldwide epidemic related to heart disease and stroke: executive summary. Circulation 2004;110:2968-75.

[5] Klein S, Burke LE, Bray GA, Blair S, Allison DB, Pi-Sunyer X, et al. Clinical implications of obesity with specific focus on cardiovascular disease: a statement for professionals from the American Heart Association Council on Nutrition, Physical Activity, and Metabolism: endorsed by the American College of Cardiology Foundation. Circulation 2004;110:2952-67.

[6] Shaw DI, Hall WL, Williams CM. Metabolic syndrome: what is it and what are the implications? Proc Nutr Soc 2005;64:349-57.

[7] DeFronzo RA, Jacot E, Jequier E, Maeder E, Wahren J, Felber JP. The effect of insulin on the disposal of intravenous glucose. Results from indirect calorimetry and hepatic and femoral venous catheterization. Diabetes 1981;30:1000-7.

[8] Shulman GI, Rothman DL, Jue T, Stein P, DeFronzo RA, Shulman RG. Quantitation of muscle glycogen synthesis in normal subjects and subjects with non-insulin-dependent diabetes by $13 \mathrm{C}$ nuclear magnetic resonance spectroscopy. N Engl J Med 1990;322:223-8.

[9] Furler SM, Poynten AM, Kriketos AD, Lowy AJ, Ellis BA, Maclean EL, et al. Independent influences of central fat and skeletal muscle lipids on insulin sensitivity. Obes Res 2001;9:535-43.

[10] Kraegen EW, Clark PW, Jenkins AB, Daley EA, Chisholm DJ, Storlien LH. Development of muscle insulin resistance after liver insulin resistance in high-fat-fed rats. Diabetes 1991;40:1397-403.

[11] Russell JC, Shillabeer G, Bar-Tana J, Lau DC, Richardson M, Wenzel LM, et al. Development of insulin resistance in the JCR:LA-cp rat: role of triacylglycerols and effects of MEDICA 16. Diabetes 1998;47:770-8.

[12] Phillips DI, Caddy S, Ilic V, Fielding BA, Frayn KN, Borthwick AC, et al. Intramuscular triglyceride and muscle insulin sensitivity: evidence for a relationship in nondiabetic subjects. Metabolism 1996;45:947-50.

[13] Pan DA, Lillioja S, Kriketos AD, Milner MR, Baur LA, Bogardus C, et al. Skeletal muscle triglyceride levels are inversely related to insulin action. Diabetes 1997;46:983-8.

[14] Schmitz-Peiffer C. Signalling aspects of insulin resistance in skeletal muscle: mechanisms induced by lipid oversupply. Cell Signal 2000;12:583-94.

[15] Rosen OM. After insulin binds. Science 1987;237:1452-8.

[16] Pessin JE, Saltiel AR. Signaling pathways in insulin action: molecular targets of insulin resistance. J Clin Invest 2000;106:165-9.

[17] Saltiel AR. New perspectives into the molecular pathogenesis and treatment of type 2 diabetes. Cell 2001;104:517-29.

[18] Alessi DR, Cohen P. Mechanism of activation and function of protein kinase B. Curr Opin Genet Dev 1998;8:55-62.

[19] Reaven GM, Hollenbeck C, Jeng CY, Wu MS, Chen YD. Measurement of plasma glucose, free fatty acid, lactate, and insulin for $24 \mathrm{~h}$ in patients with NIDDM. Diabetes 1988;37:1020-4.

[20] McGarry JD. What if Minkowski had been ageusic? An alternative angle on diabetes. Science 1992;258:766-70.

[21] Boden G, Chen X, Ruiz J, White JV, Rossetti L. Mechanisms of fatty acidinduced inhibition of glucose uptake. J Clin Invest 1994;93:2438-46.

[22] Boden G, Chen X. Effects of fat on glucose uptake and utilization in patients with non-insulin-dependent diabetes. J Clin Invest 1995;96: 1261-8.

[23] Boden G, Chen X, Rosner J, Barton M. Effects of a 48-h fat infusion on insulin secretion and glucose utilization. Diabetes 1995;44:1239-42.
[24] Krssak M, Falk Petersen K, Dresner A, DiPietro L, Vogel SM, Rothman DL, et al. Intramyocellular lipid concentrations are correlated with insulin sensitivity in humans: a 1H NMR spectroscopy study. Diabetologia 1999;42:113-6.

[25] Qvigstad E, Mostad IL, Bjerve KS, Grill VE. Acute lowering of circulating fatty acids improves insulin secretion in a subset of type 2 diabetes subjects. Am J Physiol Endocrinol Metab 2003;284:E129-37.

[26] Ahren B. Reducing plasma free fatty acids by acipimox improves glucose tolerance in high-fat fed mice. Acta Physiol Scand 2001;171:161-7.

[27] Oakes ND, Cooney GJ, Camilleri S, Chisholm DJ, Kraegen EW. Mechanisms of liver and muscle insulin resistance induced by chronic high-fat feeding. Diabetes 1997;46:1768-74.

[28] Kim JK, Wi JK, Youn JH. Metabolic impairment precedes insulin resistance in skeletal muscle during high-fat feeding in rats. Diabetes 1996;45:651-8.

[29] Storlien LH, Jenkins AB, Chisholm DJ, Pascoe WS, Khouri S, Kraegen EW. Influence of dietary fat composition on development of insulin resistance in rats. Relationship to muscle triglyceride and omega-3 fatty acids in muscle phospholipid. Diabetes 1991;40:280-9.

[30] Dobbins RL, Szczepaniak LS, Bentley B, Esser V, Myhill J, McGarry JD. Prolonged inhibition of muscle carnitine palmitoyltransferase-1 promotes intramyocellular lipid accumulation and insulin resistance in rats. Diabetes 2001;50:123-30.

[31] Boden G, Jadali F, White J, Liang Y, Mozzoli M, Chen X, et al. Effects of fat on insulin-stimulated carbohydrate metabolism in normal men. J Clin Invest 1991;88:960-6.

[32] Itani SI, Ruderman NB, Schmieder F, Boden G. Lipid-induced insulin resistance in human muscle is associated with changes in diacylglycerol, protein kinase C, and IkappaB-alpha. Diabetes 2002;51:2005-11.

[33] Boden G, Lebed B, Schatz M, Homko C, Lemieux S. Effects of acute changes of plasma free fatty acids on intramyocellular fat content and insulin resistance in healthy subjects. Diabetes 2001;50:1612-7.

[34] Gavrilova O, Marcus-Samuels B, Graham D, Kim JK, Shulman GI, Castle AL, et al. Surgical implantation of adipose tissue reverses diabetes in lipoatrophic mice. J Clin Invest 2000;105:271-8.

[35] Kim JK, Gavrilova O, Chen Y, Reitman ML, Shulman GI. Mechanism of insulin resistance in A-ZIP/F-1 fatless mice. J Biol Chem 2000;275:8456-60.

[36] Oral EA, Simha V, Ruiz E, Andewelt A, Premkumar A, Snell P, et al. Leptin-replacement therapy for lipodystrophy. N Engl J Med 2002;346:570-8

[37] Shimomura I, Hammer RE, Ikemoto S, Brown MS, Goldstein JL. Leptin reverses insulin resistance and diabetes mellitus in mice with congenital lipodystrophy. Nature 1999;401:73-6.

[38] Petersen KF, Oral EA, Dufour S, Befroy D, Ariyan C, Yu C, et al. Leptin reverses insulin resistance and hepatic steatosis in patients with severe lipodystrophy. J Clin Invest 2002;109:1345-50.

[39] Hallakou S, Doare L, Foufelle F, Kergoat M, Guerre-Millo M, Berthault MF, et al. Pioglitazone induces in vivo adipocyte differentiation in the obese Zucker falfa rat. Diabetes 1997;46:1393-9.

[40] Teranishi T, Ohara T, Maeda K, Zenibayashi M, Kouyama K, Hirota Y, et al. Effects of pioglitazone and metformin on intracellular lipid content in liver and skeletal muscle of individuals with type 2 diabetes mellitus. Metabolism 2007;56:1418-24

[41] Bruce CR, Thrush AB, Mertz VA, Bezaire V, Chabowski A, Heigenhauser GJ, et al. Endurance training in obese humans improves glucose tolerance and mitochondrial fatty acid oxidation and alters muscle lipid content. Am J Physiol Endocrinol Metab 2006;291:E99-E107.

[42] Helge JW, Wu BJ, Willer M, Daugaard JR, Storlien LH, Kiens B. Training affects muscle phospholipid fatty acid composition in humans. J Appl Physiol 2001;90:670-7.

[43] Phillips SM, Green HJ, Tarnopolsky MA, Heigenhauser GJ, Grant SM. Progressive effect of endurance training on metabolic adaptations in working skeletal muscle. Am J Physiol 1996;270:E265-72.

[44] Schrauwen-Hinderling VB, Schrauwen P, Hesselink MK, van Engelshoven JM, Nicolay K, Saris WH, et al. The increase in intramyocellular lipid content is a very early response to training. J Clin Endocrinol Metab 2003;88:1610-6.

[45] Goodpaster BH, He J, Watkins S, Kelley DE. Skeletal muscle lipid content and insulin resistance: evidence for a paradox in endurancetrained athletes. J Clin Endocrinol Metab 2001;86:5755-61. 
[46] Schmitz-Peiffer C. Protein kinase C and lipid-induced insulin resistance in skeletal muscle. Ann N Y Acad Sci 2002;967:146-57.

[47] Chen MT, Kaufman LN, Spennetta T, Shrago E. Effects of high fatfeeding to rats on the interrelationship of body weight, plasma insulin, and fatty acyl-coenzyme A esters in liver and skeletal muscle. Metabolism 1992;41:564-9.

[48] Chalkley SM, Hettiarachchi M, Chisholm DJ, Kraegen EW. Five-hour fatty acid elevation increases muscle lipids and impairs glycogen synthesis in the rat. Metabolism 1998;47:1121-6.

[49] Ellis BA, Poynten A, Lowy AJ, Furler SM, Chisholm DJ, Kraegen EW, et al. Long-chain acyl-CoA esters as indicators of lipid metabolism and insulin sensitivity in rat and human muscle. Am J Physiol Endocrinol Metab 2000;279:E554-60.

[50] Thompson AL, Lim-Fraser MY, Kraegen EW, Cooney GJ. Effects of individual fatty acids on glucose uptake and glycogen synthesis in soleus muscle in vitro. Am J Physiol Endocrinol Metab 2000;279:E577-84.

[51] Oakes ND, Bell KS, Furler SM, Camilleri S, Saha AK, Ruderman NB, et al. Diet-induced muscle insulin resistance in rats is ameliorated by acute dietary lipid withdrawal or a single bout of exercise: parallel relationship between insulin stimulation of glucose uptake and suppression of long-chain fatty acyl-CoA. Diabetes 1997;46:2022-8.

[52] Cooney GJ, Thompson AL, Furler SM, Ye J, Kraegen EW. Muscle long-chain acyl CoA esters and insulin resistance. Ann N Y Acad Sci 2002;967:196-207.

[53] Orellana A, Hidalgo PC, Morales MN, Mezzano D, Bronfman M. Palmitoyl-CoA and the acyl-CoA thioester of the carcinogenic peroxisome-proliferator ciprofibrate potentiate diacylglycerol-activated protein kinase $\mathrm{C}$ by decreasing the phosphatidylserine requirement of the enzyme. Eur J Biochem 1990;190:57-61.

[54] Nesher M, Boneh A. Effect of fatty acids and their acyl-CoA esters on protein kinase $\mathrm{C}$ activity in fibroblasts: possible implications in fatty acid oxidation defects. Biochim Biophys Acta 1994;1221:66-72.

[55] Merrill Jr AH. De novo sphingolipid biosynthesis: a necessary, but dangerous, pathway. J Biol Chem 2002;277:25843-6.

[56] Turinsky J, O'Sullivan DM, Bayly BP. 1,2-Diacylglycerol and ceramide levels in insulin-resistant tissues of the rat in vivo. J Biol Chem 1990;265: 16880-5.

[57] Straczkowski M, Kowalska I, Nikolajuk A, Dzienis-Straczkowska S, Kinalska I, Baranowski M, et al. Relationship between insulin sensitivity and sphingomyelin signaling pathway in human skeletal muscle. Diabetes 2004;53:1215-21.

[58] Adams II JM, 2nd, Pratipanawatr T, Berria R, Wang E, DeFronzo RA, Sullards MC, et al. Ceramide content is increased in skeletal muscle from obese insulin-resistant humans. Diabetes 2004;53:25-31.

[59] Hannun YA, Obeid LM. The Ceramide-centric universe of lipidmediated cell regulation: stress encounters of the lipid kind. J Biol Chem 2002;277:25847-50.

[60] Merrill Jr AH, Jones DD. An update of the enzymology and regulation of sphingomyelin metabolism. Biochim Biophys Acta 1990;1044:1-12.

[61] Murase K, Odaka H, Suzuki M, Tayuki N, Ikeda H. Pioglitazone timedependently reduces tumour necrosis factor-alpha level in muscle and improves metabolic abnormalities in Wistar fatty rats. Diabetologia 1998;41:257-64.

[62] Summers SA. Ceramides in insulin resistance and lipotoxicity. Prog Lipid Res 2006;45:42-72.

[63] Schmitz-Peiffer C, Craig DL, Biden TJ. Ceramide generation is sufficient to account for the inhibition of the insulin-stimulated PKB pathway in C2C12 skeletal muscle cells pretreated with palmitate. J Biol Chem 1999;274:24202-10.

[64] Hajduch E, Balendran A, Batty IH, Litherland GJ, Blair AS, Downes CP, et al. Ceramide impairs the insulin-dependent membrane recruitment of protein kinase B leading to a loss in downstream signalling in L6 skeletal muscle cells. Diabetologia 2001;44:173-83.

[65] Chavez JA, Knotts TA, Wang LP, Li G, Dobrowsky RT, Florant GL, et al. A role for ceramide, but not diacylglycerol, in the antagonism of insulin signal transduction by saturated fatty acids. J Biol Chem 2003;278:10297-303.

[66] Schmitz-Peiffer C, Browne CL, Oakes ND, Watkinson A, Chisholm DJ, Kraegen EW, et al. Alterations in the expression and cellular localization of protein kinase $\mathrm{C}$ isozymes epsilon and theta are associated with insulin resistance in skeletal muscle of the high-fat-fed rat. Diabetes 1997;46:169-78.
[67] Heydrick SJ, Rudermain NB, Kurowski TG, Adams HB, Chen KS. Enhanced stimulation of diacylglycerol and lipid synthesis by insulin in denervated muscle. Altered protein kinase $\mathrm{C}$ activity and possible link to insulin resistance. Diabetes 1991;40:1707-11.

[68] Cooper DR, Watson JE, Dao ML. Decreased expression of protein kinase-C alpha, beta, and epsilon in soleus muscle of Zucker obese $(\mathrm{fa} / \mathrm{fa}$ ) rats. Endocrinology 1993;133:2241-7.

[69] Saha AK, Kurowski TG, Colca JR, Ruderman NB. Lipid abnormalities in tissues of the KKAy mouse: effects of pioglitazone on malonyl-CoA and diacylglycerol. Am J Physiol 1994;267:E95-E101.

[70] Qu X, Seale JP, Donnelly R. Tissue and isoform-selective activation of protein kinase $\mathrm{C}$ in insulin-resistant obese Zucker rats - effects of feeding. J Endocrinol 1999;162:207-14.

[71] Avignon A, Standaert ML, Yamada K, Mischak H, Spencer B, Farese RV. Insulin increases mRNA levels of protein kinase $\mathrm{C}$-alpha and -beta in rat adipocytes and protein kinase $\mathrm{C}$-alpha, -beta and -theta in rat skeletal muscle. Biochem J 1995;308(Pt 1):181-7.

[72] Brose N, Betz A, Wegmeyer H. Divergent and convergent signaling by the diacylglycerol second messenger pathway in mammals. Curr Opin Neurobiol 2004;14:328-40.

[73] Carrasco S, Merida I. Diacylglycerol, when simplicity becomes complex. Trends Biochem Sci 2007;32:27-36.

[74] Haemmerle G, Zimmermann R, Hayn M, Theussl C, Waeg G, Wagner E, et al. Hormone-sensitive lipase deficiency in mice causes diglyceride accumulation in adipose tissue, muscle, and testis. J Biol Chem 2002;277:4806-15.

[75] Jenkins CM, Mankuso DJ, Yan W, Sims HF, Gibson B, Gross RW. Identification, cloning, expression, and purification of three novel human calcium-independent phospholipase A2 family members possessing triacylglycerol lipase and acylglycerol transacylase activities. J Biol Chem 2004;279:48968-75.

[76] Villena JA, Roy S, Sarkadi-Nagy E, Kim KH, Sul HS. Desnutrin, an adipocyte gene encoding a novel patatin domain-containing protein, is induced by fasting and glucocorticoids: ectopic expression of desnutrin increases triglyceride hydrolysis. J Biol Chem 2004;279:47066-75.

[77] Zimmermann R, Strauss JG, Haemmerle G, Schoiswohl G, BirnerGruenberger R, Riederer M, et al. Fat mobilization in adipose tissue is promoted by adipose triglyceride lipase. Science 2004;306:1383-6.

[78] Housey GM, O’Brian CA, Johnson MD, Kirschmeier P, Weinstein IB. Isolation of cDNA clones encoding protein kinase $\mathrm{C}$ : evidence for a protein kinase C-related gene family. Proc Natl Acad Sci U S A 1987;84:1065-9.

[79] Nishizuka Y. The molecular heterogeneity of protein kinase C and its implications for cellular regulation. Nature 1988;334:661-5.

[80] Newton AC. Protein kinase C: structure, function, and regulation. J Biol Chem 1995;270:28495-8.

[81] Nishizuka Y. The role of protein kinase $C$ in cell surface signal transduction and tumour promotion. Nature 1984;308:693-8.

[82] Nishizuka Y. Intracellular signaling by hydrolysis of phospholipids and activation of protein kinase C. Science 1992;258:607-14.

[83] Nishizuka Y. Protein kinase $\mathrm{C}$ and lipid signaling for sustained cellular responses. Faseb J 1995;9:484-96.

[84] Donnelly R, Reed MJ, Azhar S, Reaven GM. Expression of the major isoenzyme of protein kinase-C in skeletal muscle, nPKC theta, varies with muscle type and in response to fructose-induced insulin resistance. Endocrinology 1994;135:2369-74.

[85] Griffin ME, Marcucci MJ, Cline GW, Bell K, Barucci N, Lee D, et al. Free fatty acid-induced insulin resistance is associated with activation of protein kinase $\mathrm{C}$ theta and alterations in the insulin signaling cascade. Diabetes 1999;48:1270-4.

[86] Bandyopadhyay G, Kanoh Y, Sajan MP, Standaert ML, Farese RV. Effects of adenoviral gene transfer of wild-type, constitutively active, and kinase-defective protein kinase C-lambda on insulin-stimulated glucose transport in L6 myotubes. Endocrinology 2000;141:4120-7.

[87] Karasik A, Rothenberg PL, Yamada K, White MF, Kahn CR. Increased protein kinase $\mathrm{C}$ activity is linked to reduced insulin receptor autophosphorylation in liver of starved rats. J Biol Chem 1990;265: 10226-31.

[88] Kellerer M, Mushack J, Mischak H, Haring HU. Protein kinase C (PKC) epsilon enhances the inhibitory effect of TNF alpha on insulin signaling in HEK293 cells. FEBS Lett 1997;418:119-22. 
[89] Liu YF, Herschkovitz A, Boura-Halfon S, Ronen D, Paz K, Leroith D, et al. Serine phosphorylation proximal to its phosphotyrosine binding domain inhibits insulin receptor substrate 1 function and promotes insulin resistance. Mol Cell Biol 2004;24:9668-81.

[90] Paz K, Hemi R, LeRoith D, Karasik A, Elhanany E, Kanety H, et al. A molecular basis for insulin resistance. Elevated serine/threonine phosphorylation of IRS-1 and IRS-2 inhibits their binding to the juxtamembrane region of the insulin receptor and impairs their ability to undergo insulin-induced tyrosine phosphorylation. J Biol Chem 1997;272:29911-8.

[91] Tanti JF, Gremeaux T, van Obberghen E, Le Marchand-Brustel Y. Serine/ threonine phosphorylation of insulin receptor substrate 1 modulates insulin receptor signaling. J Biol Chem 1994;269:6051-7.

[92] Kim JK, Fillmore JJ, Sunshine MJ, Albrecht B, Higashimori T, Kim DW, et al. PKC-theta knockout mice are protected from fat-induced insulin resistance. J Clin Invest 2004;114:823-7.

[93] Um SH, Frigerio F, Watanabe M, Picard F, Joaquin M, Sticker M, et al. Absence of S6K1 protects against age- and diet-induced obesity while enhancing insulin sensitivity. Nature 2004;431:200-5.

[94] Furukawa N, Ongusaha P, Jahng WJ, Araki K, Choi CS, Kim HJ, et al. Role of Rho-kinase in regulation of insulin action and glucose homeostasis. Cell Metab 2005;2:119-29.

[95] Hirosumi J, Tuncman G, Chang L, Gorgun CZ, Uysal KT, Maeda K, et al. A central role for JNK in obesity and insulin resistance. Nature 2002;420:333-6.

[96] Morino K, Petersen KF, Dufour S, Befroy D, Frattini J, Shatzkes N, et al. Reduced mitochondrial density and increased IRS-1 serine phosphorylation in muscle of insulin-resistant offspring of type 2 diabetic parents. J Clin Invest 2005;115:3587-93.

[97] Mothe I, Van Obberghen E. Phosphorylation of insulin receptor substrate-1 on multiple serine residues, $612,632,662$, and 731 , modulates insulin action. J Biol Chem 1996;271:11222-7.

[98] Aguirre V, Werner ED, Giraud J, Lee YH, Shoelson SE, White MF. Phosphorylation of Ser307 in insulin receptor substrate-1 blocks interactions with the insulin receptor and inhibits insulin action. J Biol Chem 2002;277:1531-7.

[99] Moeschel K, Beck A, Weigert C, Lammers R, Kalbacher H, Voelter W, et al. Protein kinase C-zeta-induced phosphorylation of Ser318 in insulin receptor substrate-1 (IRS-1) attenuates the interaction with the insulin receptor and the tyrosine phosphorylation of IRS-1. J Biol Chem 2004;279:25157-63.

[100] Li J, DeFea K, Roth RA. Modulation of insulin receptor substrate-1 tyrosine phosphorylation by an Akt/phosphatidylinositol 3-kinase pathway. J Biol Chem 1999;274:9351-6.

[101] Yu C, Chen Y, Cline GW, Zhang D, Zong H, Wang Y, et al. Mechanism by which fatty acids inhibit insulin activation of insulin receptor substrate-1 (IRS-1)-associated phosphatidylinositol 3-kinase activity in muscle. J Biol Chem 2002;277:50230-6.

[102] Schmitz-Peiffer C, Oakes ND, Browne CL, Kraegen EW, Biden TJ, et al. Reversal of chronic alterations of skeletal muscle protein kinase $\mathrm{C}$ from fat-fed rats by BRL-49653. Am J Physiol 1997;273:E915-21.

[103] Bell KS, Schmitz-Peiffer C, Lim-Fraser M, Biden TJ, Clooney GJ, Kraegen EW. Acute reversal of lipid-induced muscle insulin resistance is associated with rapid alteration in PKC-theta localization. Am J Physiol Endocrinol Metab 2000;279:E1196-201.

[104] Itani SI, Pories WJ, Macdonald KG, Dohm GL. Increased protein kinase C theta in skeletal muscle of diabetic patients. Metabolism 2001;50:553-7.

[105] Sebastian D, Herrero L, Serra D, Asins G, Hegardt FG. CPT I overexpression protects L6E9 muscle cells from fatty acid-induced insulin resistance. Am J Physiol Endocrinol Metab 2007;292:E677-86.

[106] Ntambi JM, Miyazaki M, Stoehr JP, Lan H, Kendziorski CM, Yandell BS, et al. Loss of stearoyl-CoA desaturase-1 function protects mice against adiposity. Proc Natl Acad Sci U S A 2002;99:11482-6.

[107] Hammond LE, Gallagher PA, Wang S, Hiller S, Kluckman KD, Posey-Marcos EL, et al. Mitochondrial glycerol-3-phosphate acyltransferase-deficient mice have reduced weight and liver triacylglycerol content and altered glycerolipid fatty acid composition. Mol Cell Biol 2002;22: 8204-14.

[108] Cases S, Smith SJ, Zheng YW, Myers HM, Lear SR, Sande E, et al. Identification of a gene encoding an acyl CoA:diacylglycerol acyltransferase, a key enzyme in triacylglycerol synthesis. Proc Natl Acad Sci U S A 1998;95: $13018-23$.
[109] Cases S, Stone SJ, Zhou P, Yen E, Tow B, Lardizabal KD, et al. Cloning of DGAT2, a second mammalian diacylglycerol acyltransferase, and related family members. J Biol Chem 2001;276: 38870-6.

[110] Farese Jr RV, Cases S, Smith SJ. Triglyceride synthesis: insights from the cloning of diacylglycerol acyltransferase. Curr Opin Lipidol 2000;11:229-34.

[111] Stone SJ, Myers HM, Watkins SM, Brown BE, Feingold KR, Elias PM, et al. Lipopenia and skin barrier abnormalities in DGAT2-deficient mice. J Biol Chem 2004;279:11767-76.

[112] Chen HC, Smith SJ, Ladha Z, Jensen DR, Ferreira LD, Pulawa LK, et al. Increased insulin and leptin sensitivity in mice lacking acyl CoA: diacylglycerol acyltransferase 1. J Clin Invest 2002;109:1049-55.

[113] Chen HC, Rao M, Sajan MP, Standaert M, Kanoh Y, Miura A, et al. Role of adipocyte-derived factors in enhancing insulin signaling in skeletal muscle and white adipose tissue of mice lacking Acyl CoA:diacylglycerol acyltransferase 1. Diabetes 2004;53:1445-51.

[114] Chen HC, Farese Jr RV. Inhibition of triglyceride synthesis as a treatment strategy for obesity: lessons from DGAT1-deficient mice. Arterioscler Thromb Vasc Biol 2005;25:482-6.

[115] Chen HC, Stone SJ, Zhou P, Buhman KK, Farese Jr RV. Dissociation of obesity and impaired glucose disposal in mice overexpressing acyl coenzyme a:diacylglycerol acyltransferase 1 in white adipose tissue. Diabetes 2002;51:3189-95.

[116] Smith SJ, Cases S, Jensen DR, Chen HC, Sande E, Tow B, et al. Obesity resistance and multiple mechanisms of triglyceride synthesis in mice lacking Dgat. Nat Genet 2000;25:87-90.

[117] Chen HC, Jensen DR, Myers HM, Eckel RH, Farese Jr RV. Obesity resistance and enhanced glucose metabolism in mice transplanted with white adipose tissue lacking acyl CoA:diacylglycerol acyltransferase 1. J Clin Invest 2003; 111:1715-22.

[118] Fruebis J, Tsao TS, Javorschi S, Ebbets-Reed D, Erickson MR, Yen FT, et al. Proteolytic cleavage product of $30-\mathrm{kDa}$ adipocyte complement-related protein increases fatty acid oxidation in muscle and causes weight loss in mice. Proc Natl Acad Sci U S A 2001;98:2005-10.

[119] Maeda N, Shimomura I, Kishida K, Nishizawa H, Matsuda M, Nagaretani $\mathrm{H}$, et al. Diet-induced insulin resistance in mice lacking adiponectin/ACRP30. Nat Med 2002;8:731-7.

[120] Yen CL, Monetti M, Burri BJ, Farese Jr RV. The triacylglycerol synthesis enzyme DGAT1 also catalyzes the synthesis of diacylglycerols, waxes, and retinyl esters. J Lipid Res 2005;46:1502-11.

[121] Liu L, Zhang Y, Chen N, Shi X, Tsang B, Yu YH. Upregulation of myocellular DGAT1 augments triglyceride synthesis in skeletal muscle and protects against fat-induced insulin resistance. J Clin Invest 2007;117:1679-89.

[122] Schenk S, Horowitz JF. Acute exercise increases triglyceride synthesis in skeletal muscle and prevents fatty acid-induced insulin resistance. J Clin Invest 2007;117:1690-8.

[123] Ikeda S, Miyazaki H, Nakatani T, Kai Y, Kamei Y, Miura S, et al. Upregulation of SREBP-1c and lipogenic genes in skeletal muscles after exercise training. Biochem Biophys Res Commun 2002;296:395-400.

[124] Chavez JA, Summers SA. Characterizing the effects of saturated fatty acids on insulin signaling and ceramide and diacylglycerol accumulation in 3T3-L1 adipocytes and C2C12 myotubes. Arch Biochem Biophys 2003;419:101-9.

[125] Montell E, Turini M, Marotta M, Roberts M, Noe V, Ciudad CJ, et al. DAG accumulation from saturated fatty acids desensitizes insulin stimulation of glucose uptake in muscle cells. Am J Physiol Endocrinol Metab 2001;280:E229-37.

[126] Gaster M, Rustan AC, Beck-Nielsen H. Differential utilization of saturated palmitate and unsaturated oleate: evidence from cultured myotubes. Diabetes 2005;54:648-56.

[127] Coleman R, Bell RM. Triacylglycerol synthesis in isolated fat cells. Studies on the microsomal diacylglycerol acyltransferase activity using ethanol-dispersed diacylglycerols. J Biol Chem 1976;251:4537-43.

[128] Sauro VS, Strickland KP. Triacylglycerol synthesis and diacylglycerol acyltransferase activity during skeletal myogenesis. Biochem Cell Biol 1990;68:1393-401.

[129] Vessby B, Unsitupa M, Hermansen K, Riccardi G, Rivellese AA, Tapsell LC, et al. Substituting dietary saturated for monounsaturated fat impairs insulin sensitivity in healthy men and women: The KANWU Study. Diabetologia 2001;44:312-9. 